\title{
FABRICATION AND SURFACE MODIFICATION OF PT NANOWIRES FOR GLUCOSE DETECTION
}

\author{
Pham Xuan Thanh Tung, Pham Van Binh, Dang Ngoc Thuy Duong, Phan Thi Hong Thuy, Tran \\ Phu Duy, Le Thi Thanh Tuyen, Dang Mau Chien, Tong Duy Hien \\ Laboratory for Nanotechnology,VNU-HCM \\ (Manuscript Received on April $5^{\text {th }}$, 2012, Manuscript Revised May 15 $5^{\text {th }}, 2013$ )
}

\begin{abstract}
In this paper we present a new fabrication technique that only uses conventional techniques of microtechnology such as microlithography, thin-film deposition and directional ion beam etching to makevery narrow, wafer-scale length platinum (Pt) nanowires, named deposition and etching under angles (DEA). Then fabricated Pt nanowires electrodes were modified by using several chemicals to immobilize glucose oxidase (GOD) enzyme for application in glucose detection. A cyclic voltammetry $(\mathrm{CV})$ technique was used to determine glucose concentrations. The detection results showed that GOD was immobilized on all of the tested surfaces and the highest glucose detection sensitivity of 60 $\mu M$ was obtained when the Pt nanowires were modified by PVA. Moreover, the sensors also showed very high current response when the Pt nanowires were modified with the cysteamine SAM.
\end{abstract}

Keywords: Platinum nanowires, depostion and etching under angle, surface modification, glucose oxidase, glucose detection.

\section{INTRODUCTION}

Nanoscale devices based on nanowires have been realized for applications in electronics, optics, gas, and especially biomedical sensing [1-3]. One-dimensional structures such as nanowires are particularly compelling for electronic interconnects and biosensing applications due to their suitability for large-scale high-density integration and high sensitivity to surface interactions. Although nanowires have been fabricated by various methods [4-6], simple fabrication techniques which are not only easily addressed electrically, but also maintain reasonable costs for practical application, are also highly desirable.

Surface properties are especially of concern because the interaction of any metal electrode with its environment mainly occurs at the surface, and also because of the dependence of the response on the surface state of the electrode. Many analytical applications, such as electron transfer reaction, preferential accumulation, or selective membrane permeation, can benefit from chemically modified electrodes [7-9]. Other important applications including electrochromic display devices, controlled release of drugs, electrosynthesis, corrosion protection, etc [1014] can also benefit from the rational design of

\section{Trang 26}


electrode surfaces. Accordingly, deliberate modification of electrode surfaces can thus meet the needs of many electroanalytical problems [15, 16], and may form the basis for new analytical applications [17-19] and different sensing devices $[20,21]$. One of the most important applications of platinum (Pt) nanowires electrode is glucose detection. To obtain a sensitive and realizable Pt-based glucose biosensor, one of the key steps is enzyme immobilization on the Pt surface for subsequence catalyst oxidation of glucose into sensible products. Up to now, various modification techniques have been applied in surface activation to immobilize the enzyme onto the Pt microwire electrode surface such as physical adsorption [22], entrapment [23], covalent binding [24], cross linking, etc.

In this paper we present a new fabrication technique that only uses conventional techniques of microtechnology such as microlithography, thin-film deposition and directional ion beam etching, named deposition and etching under angles (DEA). The DEA technique can make very narrow, wafer-scale length platinum $(\mathrm{Pt})$ nanowires. $\mathrm{Pt}$ nanowire arrays, with wire width down to $30 \mathrm{~nm}$ and wire length up to several millimeters, have been realized on silicon chips. Additionally, the fabricated Pt nanowires are realized with electrical contact paths, and thus are ready for further electrical measurement and applications. Fabricated Pt nanowires electrodes were immobilized with GOD by using different techniques to investigate three generations of glucose sensor. In the first generation, enzymes were immobilized via membrane silica-gel $\left(\mathrm{SiO}_{2}+\right.$ gelatin $)$. This membrane creates a flexible matrix, negligible swelling in aqueous solution and thermal stability on the electrode [25]. In the second generation, GODs were immobilized through a polyvinyl alcohol (PVA) layer and a Prussian blue (PB) mediator. In the last generation, GOD immobilization influence was also studied for the self- assembled monolayers (SAMs) of cysteamine onto the platinum surface [26]. In addition, the performance of the glucose biosensors, including the response time, enzymatic sensitivity and device durability, are reported.

\section{METHODS}

\subsection{Chemicals and apparatus}

D-glucose and glucose oxidase (GOx, EC $\quad 1.1 .3 .4,172000$ units $\mathrm{g}-1$ from Aspergillus niger) were purchased from Sigma Aldrich. Gelatin (Merck) solution was dissolved in $0.05 \mathrm{M}$ acetate buffer $\mathrm{pH} 5.5(\mathrm{CH} 3$ $\mathrm{COOH}, \mathrm{CH} 3 \mathrm{COONa}$ ) and stirred for $1 \mathrm{~h}$ at $70^{\circ} \mathrm{C}$. $25 \mathrm{wt} \%$ glutaraldehyde solution and tetraethyl ortho-silicat (TEOS) were purchased from Merck. SiO2 solution was prepared by mixing $0.2 \mathrm{ml}$ TEOS with $20 \mathrm{~mL}$ Ethanol $100 \%, 0.3 \mathrm{ml} \mathrm{NH} 4 \mathrm{OH}, 0.3 \mathrm{ml} \mathrm{H} 2 \mathrm{O}$ and 1 $\mathrm{ml} \mathrm{HCl}$ in a glass vial. Then the homogeneous solution was obtained by stirring the solution at $80^{\circ} \mathrm{C}$ for $7 \mathrm{~h}$. Polyvinylalcohol (PVA), cysteamine and aminopropyl triethoxylane were obtained from 
Sigma, while potassiumferricyanide $(\mathrm{K} 3 \mathrm{Fe}(\mathrm{CN}) 6)$ and ferricchloride $(\mathrm{FeCl} 3)$ were obtained from Aldrich. A $0.05 \mathrm{M}$ phosphate buffer (PBS) solution was prepared using Na2HPO4 and KH2PO4. All solutions were filtered through a syringe cellulose acetate $(0.22 \mu \mathrm{m})$ before use. Double distilled deionized water was used throughout the experiment.

All electrochemical measurements were carried out on Potentiostat/Galvanostat EG\&G273A in a three-electrode conventional cell including the gold nanowires chip as working electrode, a platinum rod $0.5 \mathrm{~mm}$ diameter was used as a counter electrode, and a $\mathrm{Ag} / \mathrm{AgCl}$ electrode as reference. All measurements were carried out under room temperature.

\subsection{Fabrication of Pt nanowires by the DEA technique}

The new fabrication process that has been developed and allows the fabrication of long and narrow Pt nanowires is shown schematically in figure 1. Briefly, a layer of $1000 \mathrm{~nm}$ silicon dioxide ( $\mathrm{SiO} 2)$ is grown on a 4 inch, (100) silicon wafer by means of wet oxidation. Conventional microlithography is then carried out to define patterns on the wafer, followed by isotropic etching of $\mathrm{SiO}_{2}$ for $1 \mathrm{~min}$ in a buffered oxide etching (BHF) solution. This isotropic etching creates an under-etching or nano-spacer with width about $65-70 \mathrm{~nm}$ below the photoresist layer.

Layers of $40 \mathrm{~nm}$ platinum $/ 5 \mathrm{~nm}$ chromium are then deposited by an E-beam evaporator with an inclined angle of $30^{\circ}$ on the surface of the patterned wafer. The typical evaporation rate is $1 \AA \mathrm{s}-1$ for both $\mathrm{Cr}$ and Pt. As the result of inclined deposition, a small part of the $\mathrm{Pt} / \mathrm{Cr}$ is deposited into the nano-spacer or hidden below the photoresist film. In our work, $\mathrm{Cr}$ is used as an adhesive material for deposition of Pt film, and the width of the hidden metallic part depends on several parameters, such as the dimensions of the nano-spacer and the inclined evaporation angle.

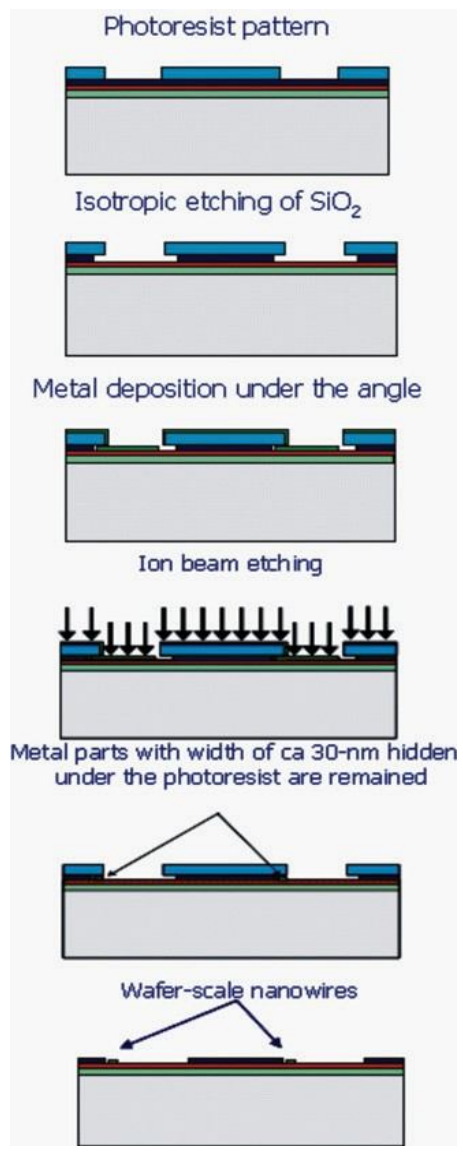

Figure 1. DEA fabrication process to make waferscale Pt nanowire using only conventional microfabrication techniques.

\section{Trang 28}




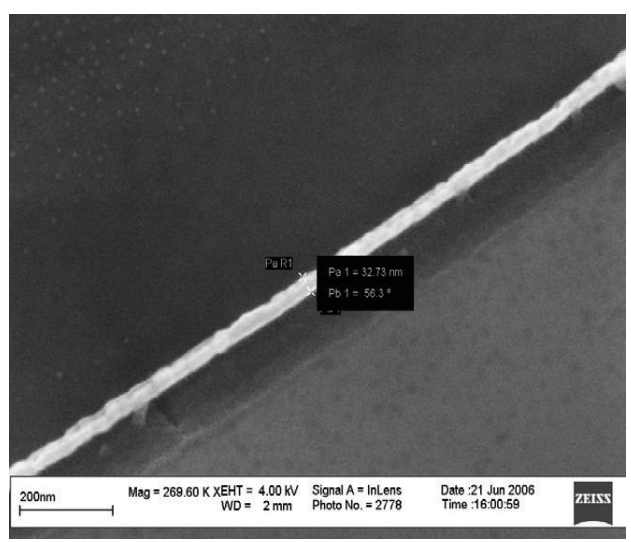

Figure 2. High resolution SEM image of the DEA fabricated Pt nanowire with width of about $32 \pm 5$ nm.

Subsequently, argon (Ar) ion beam etching (IBE) is carried out to remove the deposited $\mathrm{Pt} / \mathrm{Cr}$ film from the silicon wafer. However, the metallic parts that are hidden below the photoresist film are not being reached by the $\mathrm{Ar}$ ion flux. Thus they are not etched, and remain along and below the photoresist pattern. The remaining metallic parts have a width of about $30 \mathrm{~nm}$, therefore forming the metallic nanowires, which are $\mathrm{Pt} / \mathrm{Cr}$ nanowires in the current work. The photoresist layer is subsequently removed in a hot acetone solution to reveal the $\mathrm{Pt} / \mathrm{Cr}$ nanowires (figure 2).

Lithography is then carried out, followed by metallization to create macro contact pads for the individual $\mathrm{Pt} / \mathrm{Cr}$ nanowires. Finally, the wafer containing $\mathrm{Pt} / \mathrm{Cr}$ nanowires is diced into small chips with typical size of $7 \times 7 \mathrm{~mm}$ (fig. 3). Each diced chip has $10 \mathrm{Pt}$ nanowires several micrometers in length and about $40 \mathrm{~nm}$ in width, and any one of the realized Pt nanowires is individually electrically addressed through its contact pads at both ends (see the inset of fig. 3).

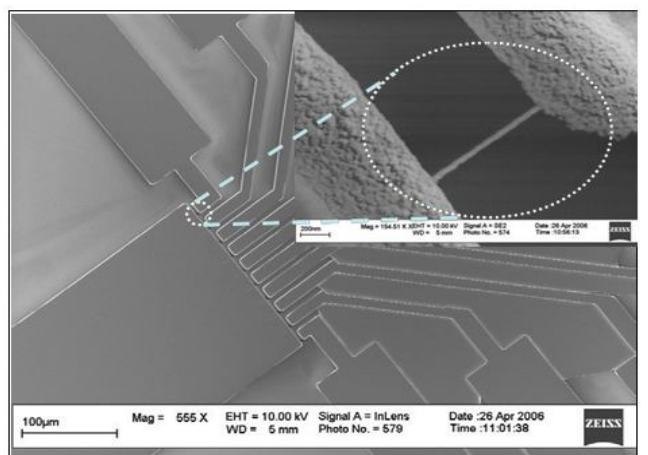

Figure 3. A diced chip contains an array of $\mathrm{Pt}$ nanowires. The inset image shows individually electrically addressed Pt nanowires, thus making the nanowires ready for measurement.

\subsection{Preparation of enzyme electrode on} different modified surface of Pt nanowire

Pt nanowires chips were immersed in dicholoromethane, propanol, acetone and deionized water (DI) for $5 \mathrm{~min}$, respectively. Then the samples were dried with blown nitrogen and cleaned by using oxygen plasma (power of $250 \mathrm{~W}$ for 6-7 min).

Then it was electrochemically scanned repeatedly until the voltammogram characteristic was obtained. In the first generation of glucose sensor, the cleaned electrode was immersed into the compound of $1 \mathrm{ml}$ gelatin-SiO2 $(3: 1 \mathrm{v} / \mathrm{v}$ mixture of concentrated gelatin, $\mathrm{SiO} 2$ stirred in $2 \mathrm{~h}$ ) and $0.5 \mathrm{ml} \mathrm{GOD}(5 \mathrm{mg} / \mathrm{ml}$ of acetate buffer, $\mathrm{pH}$ 5.5) solution. Afterwards, the electrode was dried at $4^{0} \mathrm{C}$ and washed with DI water before being used for glucose detection. In the next experiment, the electrode was reduced by scanning it in $0.001 \mathrm{M} \mathrm{H} 2 \mathrm{SO}$. Then it was 
soaked into an ethanol solution containing cysteamine $0.25 \mathrm{M}$ at $4^{0} \mathrm{C}$ for $12 \mathrm{~h}$. Afterwards, this electrode was immersed into glutaraldehyde (GAD) solution ( $5 \mathrm{mg} \mathrm{ml}-1$ of PBS buffer) for $2 \mathrm{~h}$. Finally, the modified electrode was soaked in GOD solution to bind the free enzyme from the solution onto the platinum surface.

Following the study of enzyme immobilization, PB film was electrodeposited onto the Pt nanowire surface by scanning the solution of $30 \mathrm{mM} \mathrm{K} 3 \mathrm{Fe}(\mathrm{CN}) 6,40 \mathrm{mM} \mathrm{FeCl} 3$ and $1 \mathrm{M} \mathrm{KCl}: 1 \mathrm{M} \mathrm{HCl}$ solution. The potential was scanned between $-0.2 \mathrm{~V}$ to $0.8 \mathrm{~V}$ with 50 $m V s-1$ in scan rate. In order to firm the PB mediator, we scanned it in $1 \mathrm{M} \mathrm{KCl}$ between -0.2 and $0.8 \mathrm{~V}$. Then the modified electrode was immersed successively in PVA $(5 \mathrm{mg}$ $\mathrm{ml}-1$ ) solution and aminopropyltriethoxylane $90 \%$ for 30 mins and GOD for $3 \mathrm{~h}$. In these experiments, the electrode was dried before dipping into each solution. All enzyme electrodes were kept at $4{ }^{\circ} \mathrm{C}$ until use.

\section{RESULT AND DISCUSSION}

\subsection{Fabrication of the $\mathrm{Pt} / \mathrm{Cr}$ nanowires}

Figure 2 shows a high resolution scanning electron microscopy (HR: SEM) image of the fabricated Pt nanowire. It can be seen that the realized nanowire has a width of about $32 \pm 5$ $\mathrm{nm}$. Moreover, it is straight and with a smooth surface. The obtained results prove that we have successfully developed a new fabrication method that only utilizes conventional, thus inexpensive, microfabrication techniques to realize very small Pt nanowires with good morphology.

Moreover, by adjusting several processing parameters such as the dimensions of the created nano-spacer (by varying the $\mathrm{SiO} 2$ isotropic etching step) and inclining angles during metal film deposition and IBE etching, metallic nanowires with various widths can be obtained. However, in the current work we optimized process parameters to obtain $\mathrm{Pt}$ nanowires with width of around $35 \mathrm{~nm}$, because wider nanowires may reduce the sensors' sensitivity while narrow ones may suffer the well-know problem of external noise.

Figure 3 shows a diced chip that contains an array of Pt nanowires, while the inset image shows that each nanowire from the array is individually electrically addressed. This allows the fabricated nanowires to easily be further connected to an outer electronics for detailed device measurement and applications.

\subsection{Electrical characterization of the fabricated Pt nanowires}

Figure 4 shows an $\mathrm{I}-\mathrm{V}$ characterization of the $20 \mu \mathrm{m}$ length Pt nanowires. It can be seen that the wires have good electrical characteristics with linear IV behavior of the bulk metal Pt. Moreover, the measurement results show a resistance of about $1540 \pm 40 \mathrm{~K}$ for the fabricated Pt nanowire. This value is only about $30 \%$ higher than the value calculated using the bulk material. 


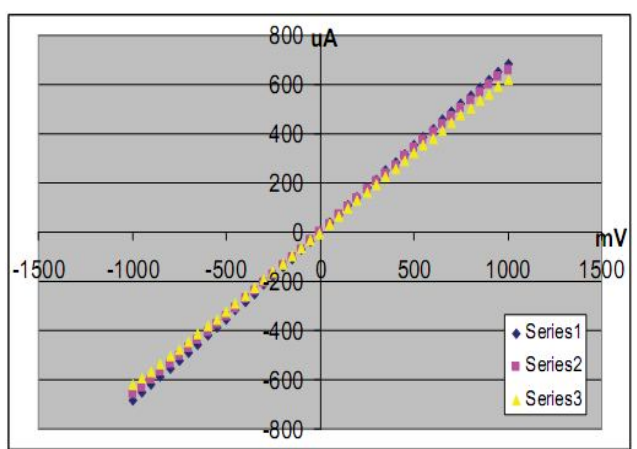

Figure 4. Current-voltage (I-V) curve, measured in ambient conditions, of the $20 \mu \mathrm{m}$ length Pt.

\subsection{Electrochemical characterization of $\mathbf{P t}$} nanowire

Cyclic voltammograms (CVs) were performed in glucose solution in PBS buffer and a variety of glucose concentrations in water to investigate the influence of electrolyte solution on the platinum electrode prior to the immobilization process. We found that the current response of the electrode did not

\subsection{Effect of pH on enzyme electrode}

The influence of $\mathrm{pH}$ buffer solution on glucose detection has been studied by several authors [7-10]. Investigation of the effect of $\mathrm{pH}$ value on the performance of the glucose sensor is very important because the activity of immobilized GOD is $\mathrm{pH}$ dependent [8]. In our work, the $\mathrm{pH}$ dependence of a modified electrode by PVA compound and PB mediator was evaluated over the $\mathrm{pH}$ range from 5.6 to 8.4. When the $\mathrm{pH}$ of the buffer was very low or very high, the GOD electrode exhibited low current response to glucose. An optimum response current was observed at a $\mathrm{pH}$ value of 7.2. appropriately change when increasing the concentration of the PBS at $0.2-0.8 \mathrm{~V}$. In contrast, when the concentration of glucose in water increased, then all peak currents decreased immediately (figure 5). That phenomenon proves that all of these elements on the electrolyte did not react together but they react with the bare Pt nanowire surface.

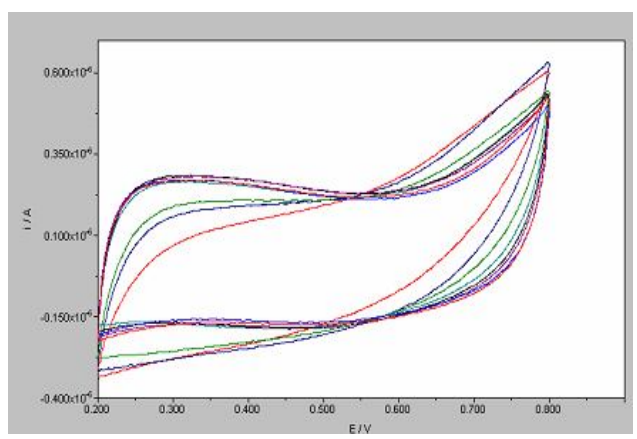

Figure 5. Current-voltage (C-V) characteristics of Pt nanowires electrode in glucose solution in various concentrations at $200 \mathrm{mVs}-1$. From inside to outside

$$
0,2.5,5,10,20 \text { and } 40 \mathrm{mM} \text {. }
$$

\subsection{Cyclic voltammograms of enzyme electrodes}

The response current of glucose on three types of biosensors was recorded and is shown in figure 6 with a potential scan rate of 100 mVs. The results show that all enzyme electrodes have high electron transfer efficiencies. We observed that with an increase in glucose concentration the redox current increased monotonously at a potential higher than $0.4 \mathrm{~V}$ and it just became stable only when the applied voltage was higher than $0.6 \mathrm{~V}$. In contrast, the $\mathrm{CV}$ curve of a gel-SiO2 modified electrode had an unstable current, and the applied voltage was higher than $0.7 \mathrm{~V}$ because of the influence of the oxygen concentration in 
electrochemical solution. This is important information for applying different immobilization membranes and the mediator. Moreover, we also found that the oxidation current or reduction current increased linearly with the concentration of glucose, and this important result is reported in detail in the next section.

\subsection{Amperometric response of glucose sensor}

Figure 7 shows the dependence on glucose concentration $(0-16 \mathrm{mM})$ of the $\mathrm{CV}$ curves of the electrodes modified by the three immobilizing methods. Obviously, the gelatin/SiO2 modified $\mathrm{Pt}$ had the lowest response current and corresponding coefficient $(\mathrm{R} 2=0.8335)$. This indicated that this

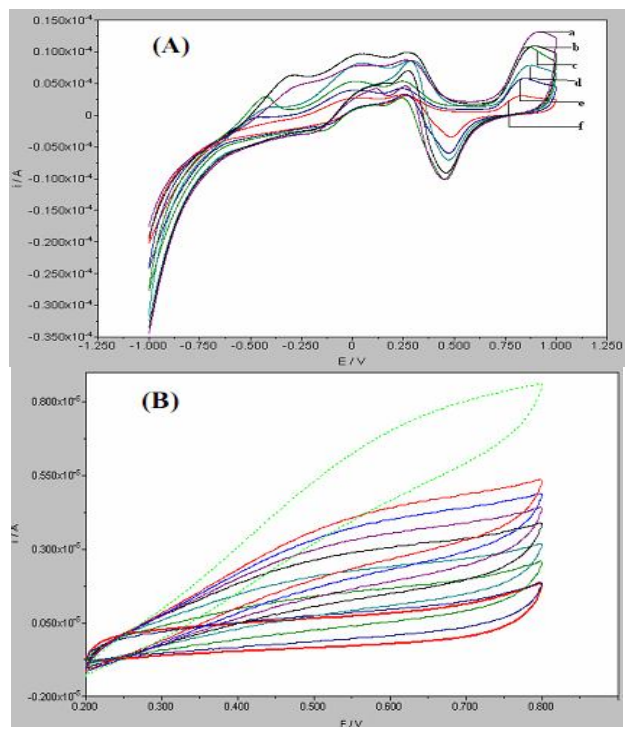

modified surface had very little immobilized enzyme, thus little $\mathrm{H} 2 \mathrm{O} 2$ was gained in the reaction with glucose. Samples with $\mathrm{PB}$ as the electron transfer mediator in PVA-PB-Pt obtained glucose detection sensitivities at 60 $\mu \mathrm{M}(\mathrm{R} 2=0.955)$. However, the highest response current was obtained with the electrode modified with the self-assembled layer of cysteamine ( $\mathrm{R} 2=0.9212)$. The modifying chemicals in this case might create a suitable microenvironment that benefits the exposition of the enzyme activity center and increases the response current. This study suggests that the enzyme immobilized on different surfaces has distinct effectiveness, thus a stable and sensitive glucose sensor may need a combination of the above immobilizing methods.

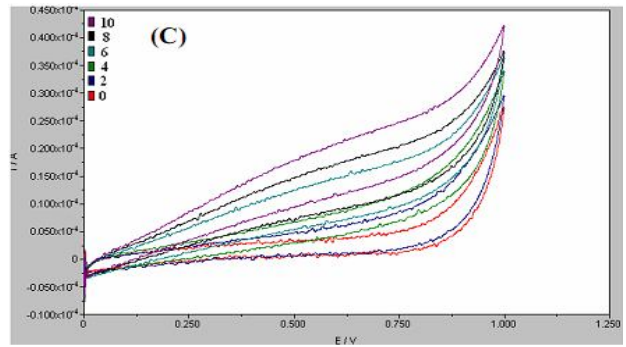

Figure 6. $\mathrm{CV}$ curves of different concentrations of glucose measured by (A) GOD-gelatinl/SiO2-Pt electrode, from down to up 0, 2, 4, 6, 8 and $16 \mathrm{mM}$; (B) GOD-PVA/PB-Pt electrode, from down to up 0, 2, 4, 8 and $12 \mathrm{mM}$; (C) GOD-cysteamine-Pt electrode, from down to up $0,2,4,6,8$ and $10 \mathrm{mM}$. 
TÄ̈ CHÍ PHAU் TRIEÅ KH\&CN, TÄ̈ 16, SOÁK1- 2013

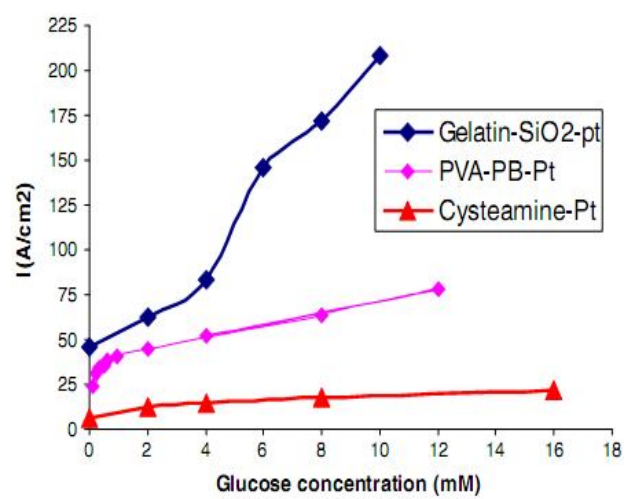

Figure 7. The response current of a glucose sensor modified by different immobilized surfaces of $\mathrm{Pt}$ nanowire at a potential of $0.6 \mathrm{~V}$.

3.7. Reproducibility and stability of the glucose sensor

The PVA-GOD modified $\mathrm{Pt}$ nanowire electrodes were prepared under the same conditions described above for detecting $3 \mathrm{mM}$

\section{CONCLUSION}

A new fabrication process, DEA, has been developed that allows successful and inexpensive fabrication of narrow but long $\mathrm{Pt}$ nanowires. The fabricated Pt nanowire chips with appropriate dimensions and properties are then utilized to build a biosensor for accurate determination of the glucose concentration in aqueous solution.

The enzyme immobilization is influenced by linking chemical groups on different $\mathrm{Pt}$ surfaces, and the response current of the $\mathrm{Pt}$ nanowire based sensor is highly dependent on glucose. The glucose sensor responses gradually decreased in the first 10 days, the activity remained constant at approximately $60 \%$ after 30 days, indicating good stability of the enzyme immobilized on the modified surfaces. Figure 8 shows the decrease in the current response, which is caused by leaking enzyme due to the loose links of the enzyme with the Pt surface after a considerable experiment period.

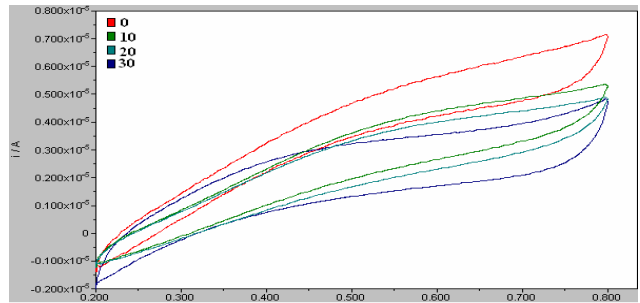

Figure 8. CV of enzyme electrode in $3 \mathrm{mM}$ glucose solution at different times. From down to up 30, 20, 20 and 0 days, respectively.

the utilized surface modification methods. Our research results reveal that GOD immobilized on the Pt nanowires, which were previously modified by PVA with a PB mediator, gave the highest glucose detection sensitivities of about $60 \mu \mathrm{M}$. The highest current response was achieved when the Pt nanowires were modified with the cysteamine SAM for subsequent binding of GOD. Furthermore, the stability and catalyst activity of the GOD were retained at about $60 \%$ after a store period of 30 days. 


\section{CHẾ TẠO VÀ HOẠT HÓA BỀ MặT SỢI NANO PLATIN ÚNG DỤNG TRONG ĐỊNH LƯỌNG GLUCOSE}

\section{Phạm Xuân Thanh Tùng, Phạm Văn Bình, Đặng Ngọc Thùy Dương, Phan Thị Hồng Thủy, Trần Phú Duy, Lê Thị Thanh Tuyền, Đặng Mậu Chiến, Tống Duy Hiển \\ PTN Công nghệ Nano, ĐHQG-HCM}

TÓM TĂT: Trong bài báo này, một phuơng pháp mới - lắng đọng và ăn mòn duới góc nghiêng (Deposition and Etching under Angle - DEA) được nghiên cứu để chế tạo số luợng lớn chip sợi nano platin ở qui mô cả phiến và các chip chế tạo ra có thể sủ dụng ngay trong các đo đạc thực nghiệm tiếp theo. Phuoong pháp chế tạo này sử dụng nhũng kỹ thuật cơ bản của công nghệ chế tạo micro thông thuờng, nhu là quang khắc quang học, lắng đọng màng mỏng và ăn mòn ion ở qui mô cả phiến, để chế tạo các dãy sợi nano platin trên phiến silic với lớp cách điện silic điôxit. Chip sợi nano platin được chế tạo bên trên sau đó được hoạt hóa bằng các loại hóa chất khác nhau nhu là hồn hợp của gel gelatin với SiO2, popyvinyl ancol (PVA) và lớp đơn phân tử tư lắp ghép cysteamine (SAM). Sau đó, enzyme glucose oxidase được gắn lên các chip đã được hoạt hóa bề mặt để xác định nồng độ glucose trong dung dịch nuớc. Kết quả khảo sát chỉ ra rằng enzyme glucose oxidase (GOD) đã được gắn kết thành công lên bề mặt sợi platin được hoạt hóa bằng các phuơng pháp nêu trên và độ nhạy cao nhất của các chip với dung dịch glucose là $60 \mu M$ với chip được hoạt hóa bằng phuơng pháp polyme hóa sủ dụng polyvinyl ancol (PVA) với màng trung chuyển điện tử là Prussian Blue (PB). Bên cạnh đó, đối với chip được hoạt hóa bằng phuoong pháp lớp đon phân tử tụ lắp ghép cysteamine thì cuờng độ dòng đo đuợc có giá trị lớn nhất.

Tù khóa: sợi nano Platin, phwơng pháp lắng đọng và ăn mòn duới góc nghiêng (DEA), hoạt hóa bề mặt, glucose oxidase, phát hiện glucose.

\section{REFERENCES}

[1]. Yun-Ze Long, Miao Yu, Bin Sun, Chang-Zhi Gu, Zhiyong Fan, Recent advances in large-scale assembly of semiconducting inorganic nanowires and nanofibers for electronics, sensors and photovoltaics, Chem. Soc. Rev., 41, 4560 (2012).

[2]. Xia Y, Yang P, Sun Y, Wu Y, Mayers B, Yin Y, Kim Fand Yan H., One-
Dimensional Nanostructures: Synthesis, Characterization, and Applications, $A d v$. Mater. 15353 (2003).

[3]. Atul Kulkarni, Yang Xu, Chisung Ahn, Rashid Amin, Sung Ha Park, Taesung Kim, Minho Lee, The label free DNA sensor using a silicon nanowire array, Journal of Biotechnology16091 (2012).

[4]. Tong H D, Carlen E T, Novel Top-Down Wafer-Scale Fabrication of Single Crystal 
Silicon Nanowires, Nanoletters, 9, 1015 (2009).

[5]. Offermans P, Tong H D, Ultralow-power hydrogen sensing with single palladium nanowires, Appl. Phys. Lett., 94223110 (2009).

[6]. G. Pennelli, M. Totaro, M. Piotto, Selective Doping of Silicon Nanowires by Means of Electron Beam Stimulated Oxide Etching, Nano Lett., 12, 1096 (2012).

[7]. Michael D. Bronshtein, Renat R. Nazmutdinov, Wolfgang Schmickler, An approach to optimised calculations of the potential energy surfaces for the case of electron transfer reactions at a metal/solution interface, Chem. Phys. Lett., 399, 307 (2004).

[8]. Caron G, Ermondi G, Damiano A, Novaroli L, Tsinman O, Ruell JA, Avdeef A Ionization, lipophilicity, and molecular modeling to investigate permeability and other biological properties of amlodipine, Bioorg Med Chem., Dec 1, 12, 6107 (2004).

[9]. P. S. Smertenko, O. P. Dimitriev, S. Schrader, L. Brehmer, Doping of polyaniline by transition metal salts: current-voltage characteristics of the ITO/polymer film/metal heterostructures, Synth. Met. 146, 187 (2004).

[10]. Gregory G. Wildgoose, Debora Giovanelli, Nathan S. Lawrence, RichardG. Compton, High-Temperature Electrochemistry: A Review Electroanalysis, 16, 421 (2004).
[11]. C. Martin, H. Huser, K. Servat, K.B. Kokoh, Electrosynthesis of lactic acid on copper and lead cathodes in aqueous media, Electrochim. Acta 51, 111 (2005).

[12]. Thierry Pauporté, A Simplified Method for WO 3 Electrodeposition J., Electrochem. Soc. 149 C539 (2002).

[13]. Aziz Yaǧan, Nuran Özçiçek Pekmez, Attila Yildiz, Electropolymerization of poly(N-methylaniline) on mild steel: Synthesis, characterization and corrosion protection Jounal of Electroanal. Chem. 578, 231 (2005).

[14]. Xia Zhong, Ruo Yuan, Yaqin Chai, Jianyuan Dai, Yan Liu, Dianping Tang, An Amperometric Biosensor for Glucose Based on Self-Assembling Nanoparticles and Electrosynthesis of Poly-o-Diaminobenzene on the Prussian Blue-Modified Gold Electrode Analytical Letters 38, 1085 (2005).

[15]. A Malinauskas, R. Garjonyt, R. Mažeikien, I. Jurevičiūt, Electrochemical response of ascorbic acid at conducting and electrogenerated polymer modified electrodes for electroanalytical applications: a review Talanta, 64, 121 (2004).

[16]. RichardG. Compton, John S. Foord and Frank Marken Electroanalysis at DiamondLike and Doped-Diamond Electrodes Electroanalysis, 15, 1349 (2003). 
[17]. Shouguo Wu, Gang Liu, Ping Lia, Hao Liu, Haihong $\mathrm{Xu}, \mathrm{A}$ high-sensitive and fast-fabricated glucose biosensor based on Prussian blue/topological insulator Bi2Se3 hybrid film Biosens, Bioelectron., 38, 289 (2012).

[18]. Fabio R. Caetano, Ava Gevaerd, Eryza G. Castro, Márcio F. Bergamini, Aldo J.G. Zarbin, Luiz H. Marcolino-Junior, Electroanalytical application of a screenprinted electrode modified by dodecanethiol-stabilized platinum nanoparticles for dapsone determination Electrochimica Acta, 66, 265 (2012).

[19]. Zuzana Navrátilová and Petr Kula Clay Modified Electrodes: Present Applications and Prospects, Electroanalysis, 15, 837 (2003).

[20]. Xiao-Rong Li, Fen-Ying Kong, Jing Liu, Tong-Ming Liang, Jing-Juan Xu, HongYuan Chen, Synthesis of PotassiumModified Graphene and Its Application in Nitrite-Selective Sensing, Advanced Functional Materials, 22, 1981 (2012).

[21]. Ta-Jen Li, Chia-Yu Lin, A. Balamurugan, Chung-Wei Kung, Jen-Yuan Wang, ChihWei Hu, Chun-Chieh Wang, Po-Yen Chen, R. Vittala, Kuo-Chuan Ho, Modification of glassy carbon electrode with a polymer/mediator composite and its application for the electrochemical detection of iodate, Analytica Chimica Acta 737, 55 (2012).

[22]. Chuanxin He, Jianhong Liu, Qianling Zhang, Chi Wu, A novel stable amperometric glucosebiosensor based on the adsorption of glucose oxidase on poly(methyl methacrylate)-bovine serum albumin core-shell nanoparticles, Sensors and Actuators B 166-167, 802 (2012).

[23]. Juliana Coatrini Soares, André Brisolari1, Valquíria da Cruz Rodrigues, Edgar Aparecido Sanches, Débora Gonçalves, Amperometric urea biosensors based on the entrapment of urease in polypyrrole films, Reactive and Functional Polymers, 72, 148 (2012).

[24]. Stéphane Marinesco et al, Covalentenzyme immobilization by poly(ethylene glycol) diglycidyl ether (PEGDE) for microelectrode biosensor preparation, Biosensors and Bioelectronics, 26, 3993 (2011).

[25]. ChoiHN, Amperometric glucose biosensor based on sol-gel-derived metal oxide/Nafion composite films, Anal. Chim. Acta, 537, 179 (2005).

[26]. Soichi Y, Mizutani F, Yukari S, Yoshiki H, Immobilization of polyglutamate-glucose oxidase onto a cysteamine-modified gold electrode, Sensors Actuators, 91187 (2003). 